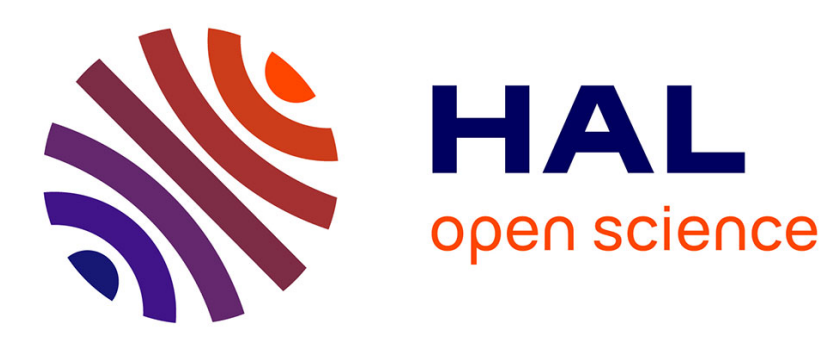

\title{
Inoculants of leguminous crops for mitigating soil emissions of the greenhouse gas nitrous oxide
}

\author{
Catherine C. Hénault, Cécile Revellin
}

\section{To cite this version:}

Catherine C. Hénault, Cécile Revellin. Inoculants of leguminous crops for mitigating soil emissions of the greenhouse gas nitrous oxide. Agricultural Ecology Research : its role in delivering sustainable farm systems, Jun 2011, Dundee, United Kingdom. hal-02746096

\section{HAL Id: hal-02746096 \\ https://hal.inrae.fr/hal-02746096}

Submitted on 3 Jun 2020

HAL is a multi-disciplinary open access archive for the deposit and dissemination of scientific research documents, whether they are published or not. The documents may come from teaching and research institutions in France or abroad, or from public or private research centers.
L'archive ouverte pluridisciplinaire HAL, est destinée au dépôt et à la diffusion de documents scientifiques de niveau recherche, publiés ou non, émanant des établissements d'enseignement et de recherche français ou étrangers, des laboratoires publics ou privés. 


\title{
Inoculants of leguminous crops for mitigating soil emissions of the greenhouse gas nitrous oxide
}

\section{Catherine Hénault and Cécile Revellin}

\begin{abstract}
UTE UMR Microbiologie des Sols et de l'Environnement - Dijon - France
\end{abstract}
EUR SOLS UR SOLS - Orléans - France 


\section{CHANGES IN ATMOSPHERIC CONCENTRATIONS OF TRACE GASES}

Atmospheric concentrations of greenhouse gases

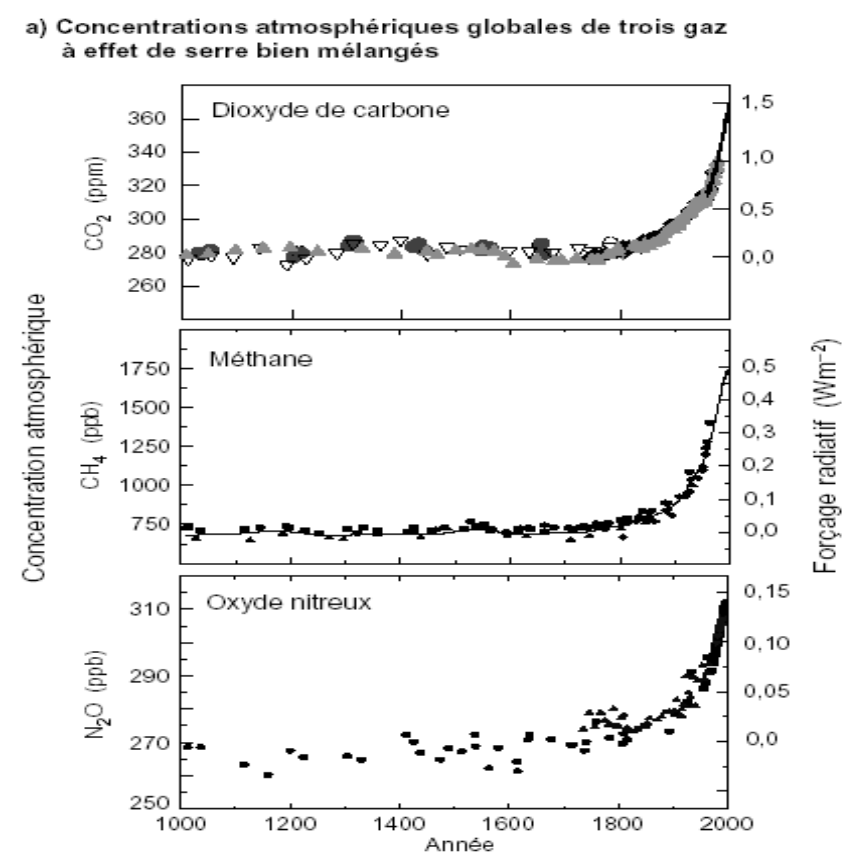

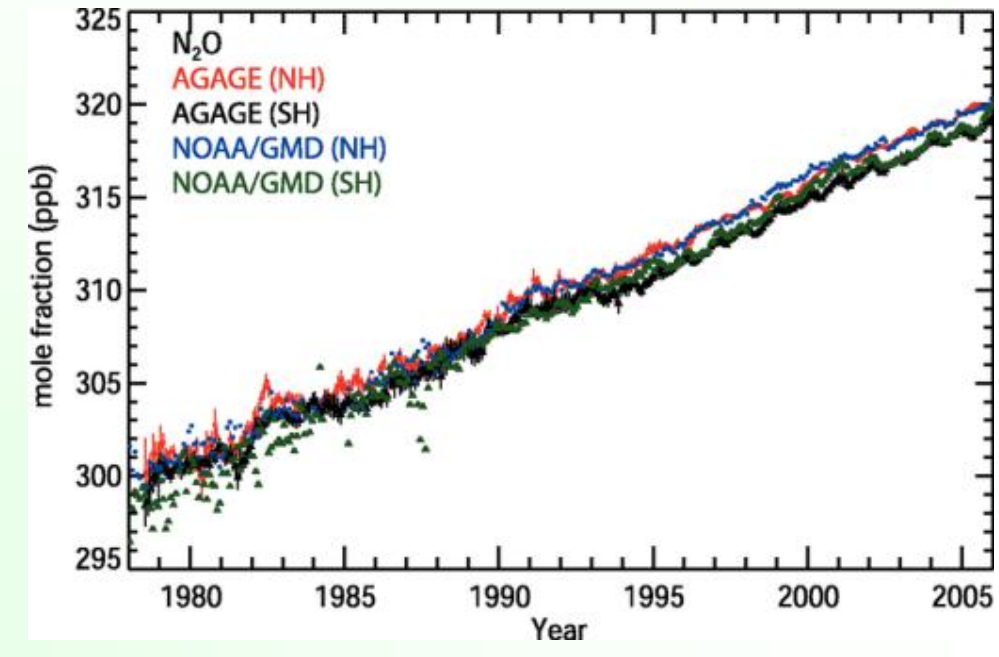

\begin{tabular}{|l|c|}
\hline GAS & GWP (100 years) \\
\hline $\mathrm{CO}_{2}$ & 1 \\
\hline $\mathrm{CH}_{4}$ & 23 \\
\hline $\mathrm{N}_{2} \mathrm{O}$ & 296 \\
\hline
\end{tabular}




\section{SOURCES OF $\mathrm{N}_{2} \mathrm{O}\left(\mathrm{Tg} \mathrm{N}-\mathrm{N}_{2} \mathrm{O}^{-1}\right)$, from IPCC 2007}

\begin{tabular}{|c|c|c|}
\hline \multicolumn{3}{|l|}{ AR4 (2007) } \\
\hline SOURCE & value & range \\
\hline \multicolumn{3}{|c|}{ Anthropogenic sources } \\
\hline Fossil fuel combustion and Industrial processes & 0.7 & $0.2-1.8$ \\
\hline Agriculture & 2.8 & $1.7-4.8$ \\
\hline Rivers, estuaries, coastal zones & 1.7 & $0.5-2.9$ \\
\hline Biomass and biofuel burning & 0.7 & $0.2-1.0$ \\
\hline Human excreta & 0.2 & $0.1-0.3$ \\
\hline Atmospheric deposition & 0.6 & $0.3-0.9$ \\
\hline Anthropogenic total & 6.7 & \\
\hline \multicolumn{3}{|c|}{ Natural sources } \\
\hline Soils under natural vegetation & 6.6 & 3.3-9.0 \\
\hline Oceans & 3.8 & $1.8-5.8$ \\
\hline Atmospheric chemistry & 0.6 & $0.3-1.2$ \\
\hline Natural sources total & 11 & \\
\hline Total sources & 17.7 & 8.5-27.7 \\
\hline Atmospheric sink & 12.3 & \\
\hline Atmopheric increase & 3.9 & \\
\hline Unbalanced & $1.5 ? ? ?$ & large range \\
\hline
\end{tabular}




\section{MECHANISMS INVOLVED IN $\mathrm{N}_{\mathbf{2}} \mathrm{O}$ BUDGET IN SOILS}

\section{ATMOSPHERE}

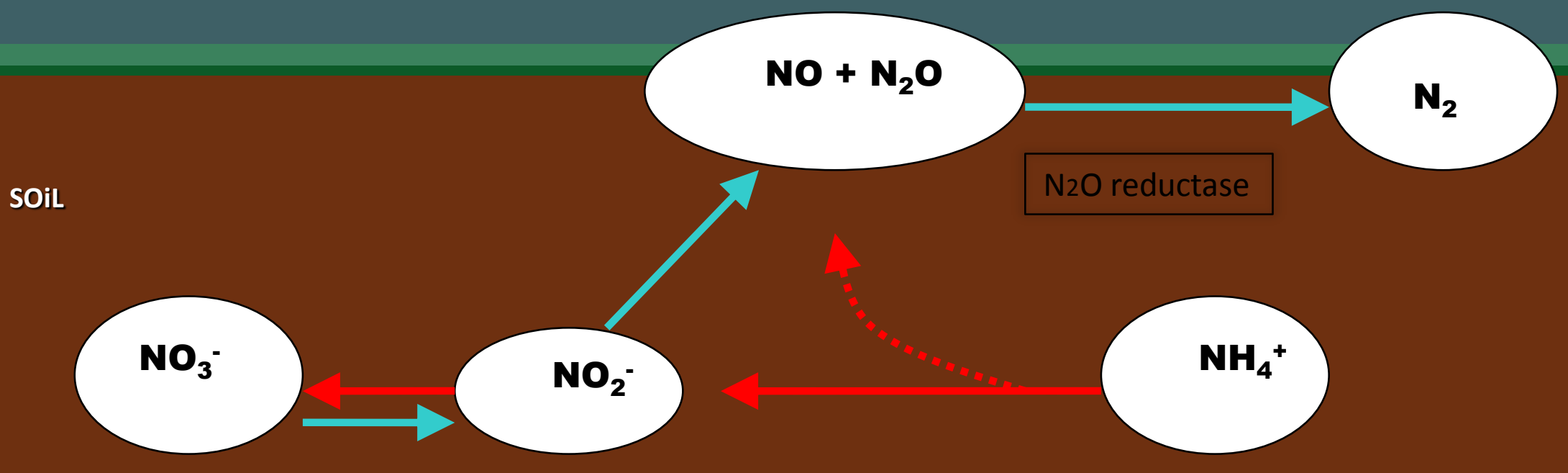

\section{denitrification (anaerobic) - nitrification (aerobic)}




\section{REGULATION OF THE LEVEL OF $\mathrm{N}_{2} \mathrm{O}$ EMISSION BY THE REDUCTION OF $\mathrm{N}_{\mathbf{2}} \mathrm{O}$}

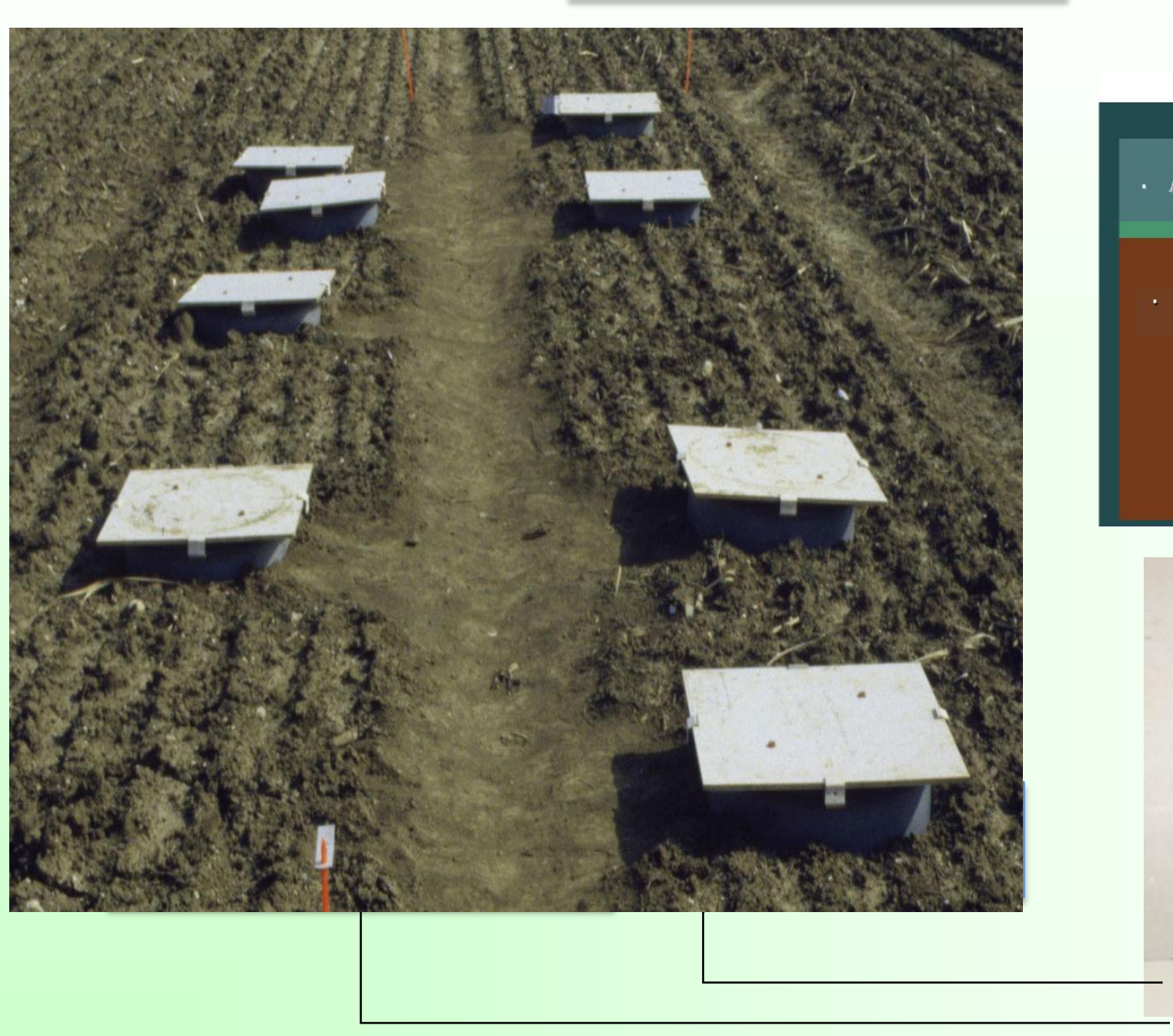

ATMOSPHERE

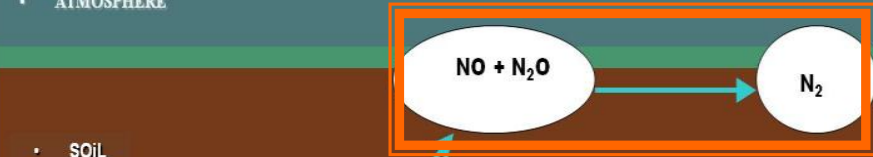

soit

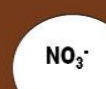

$\mathrm{NO}_{2} \cdot$

$\mathrm{NH}_{4}{ }^{+}$

Study of $\mathrm{N}_{2} \mathrm{O}$ production by the first steps of denitrification and by nitrification

\section{Study of $\mathrm{N}_{2} \mathrm{O}$} Consumption

(From Hénault et al., 2001) 


\section{OBJECTIVES OF THE STUDY}

$>$ To mitigate $\mathrm{N}_{2} \mathrm{O}$ emission by managing the $\mathrm{N}_{2} \mathrm{O}$ to $\mathrm{N}_{2}$ reduction, specially in soils where this function is inefficient

$>$ By managing soil microbial communities : use of microorganisms that grow in symbiosis with crop plants

$>$ Some rhizobia, symbionts of leguminous crops possess the nos $Z$ genes coding for the enzyme involved in the $\mathrm{N}_{2} \mathrm{O}$ reduction (Sameshima-Saito et al., 2006)

$\Rightarrow$ To crop some leguminous

- Inoculated with strains carrying the nosZ genes

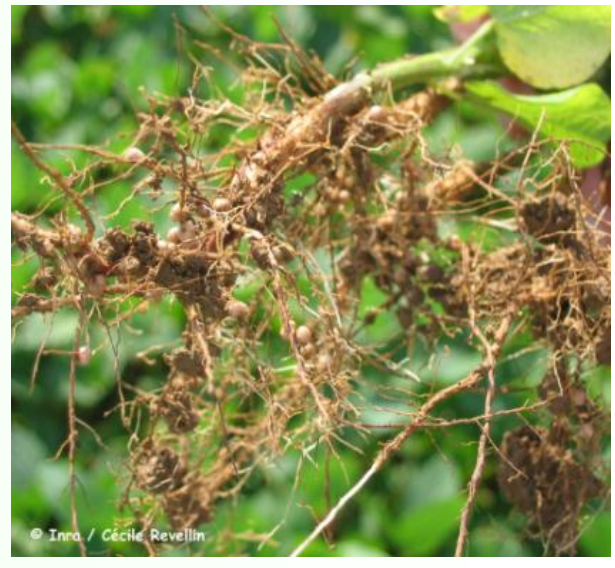

- On soil emitting high levels of $\mathrm{N}_{2} \mathrm{O}$ due to an inefficient $\mathrm{N}_{2} \mathrm{O}$ reduction

$[\mathrm{SOIL}]_{\mathrm{PhN}_{2} \mathrm{ORed}-}+[\text { Plant }+ \text { Inoculant }]_{\mathrm{PhN}_{2} \mathrm{Ored}+} \Rightarrow[\mathrm{SOIL}+\text { Plant }+ \text { Inoculant }]_{\mathrm{PhN}_{2} \mathrm{ORed}+}$ 


\section{STEPS OF THE STUDY}

$>$ A greenhouse experiment for testing the previous equation

$[\mathrm{SOIL}]_{\mathrm{PhN}_{2} \mathrm{ORed-}-}+[\text { Plant }+ \text { Inoculant }]_{\mathrm{PhN}_{2} \mathrm{Ored}+} \Rightarrow[\mathrm{SOIL}+\text { Plant }+ \text { Inoculant }]_{\mathrm{PhN}_{2} \mathrm{ORed}+}$

$>$ Some laboratory experiments to develop knowledges on the process

$>$ A modelling approach to assess quantitative benefits of this process at the field scale

\section{MAIN USED MATERIALS}

> Soybean plants inoculated with different strains of Bradyrhizobium japonicum

$>$ Gas chromatography 


\section{GREENHOUSE EXPERIMENT}
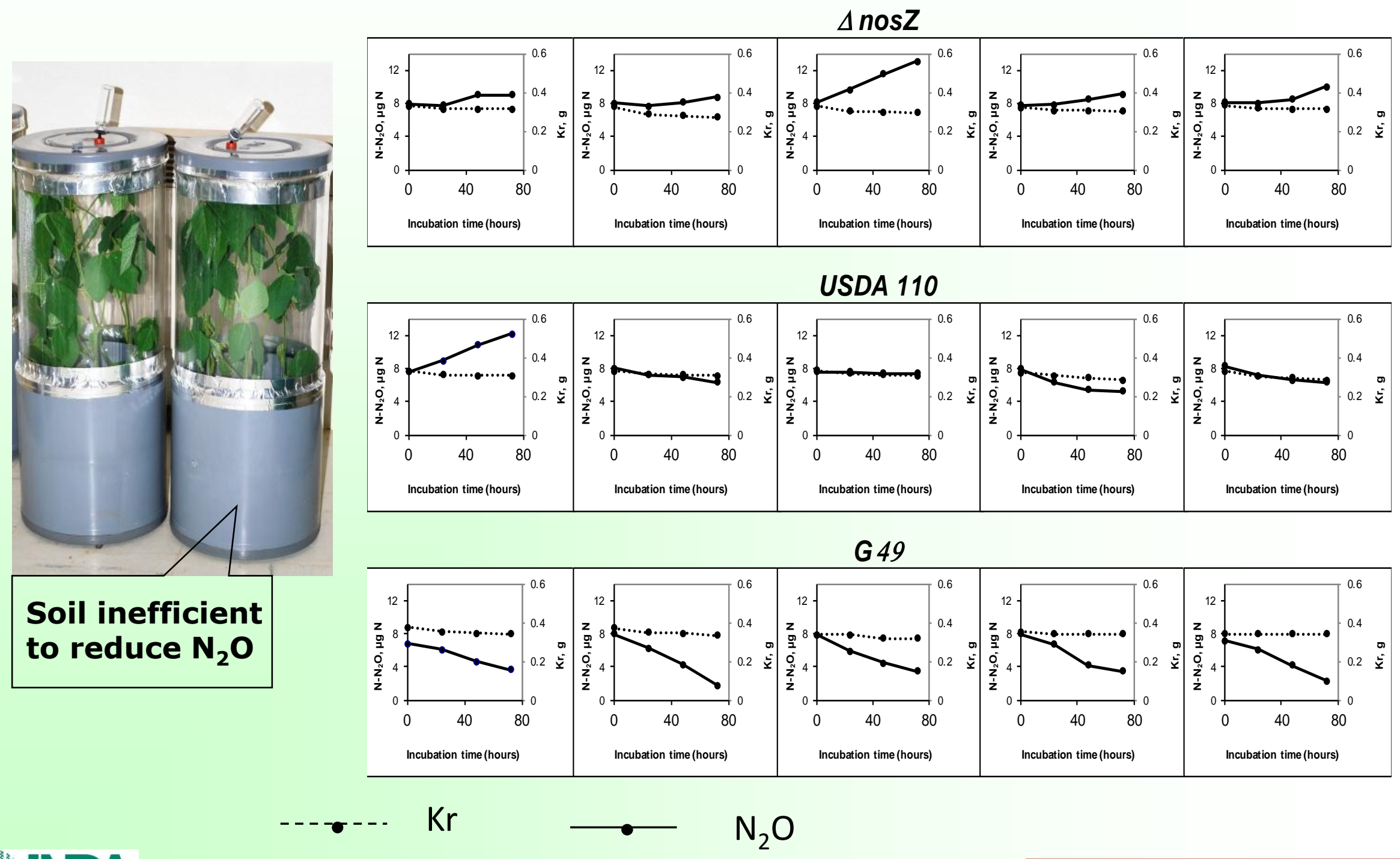

Agricultural Ecology Research: its role in delivering sustainable farm systems - Dundee, 15-16 june 2011 


\section{LABORATORY EXPERIMENT}
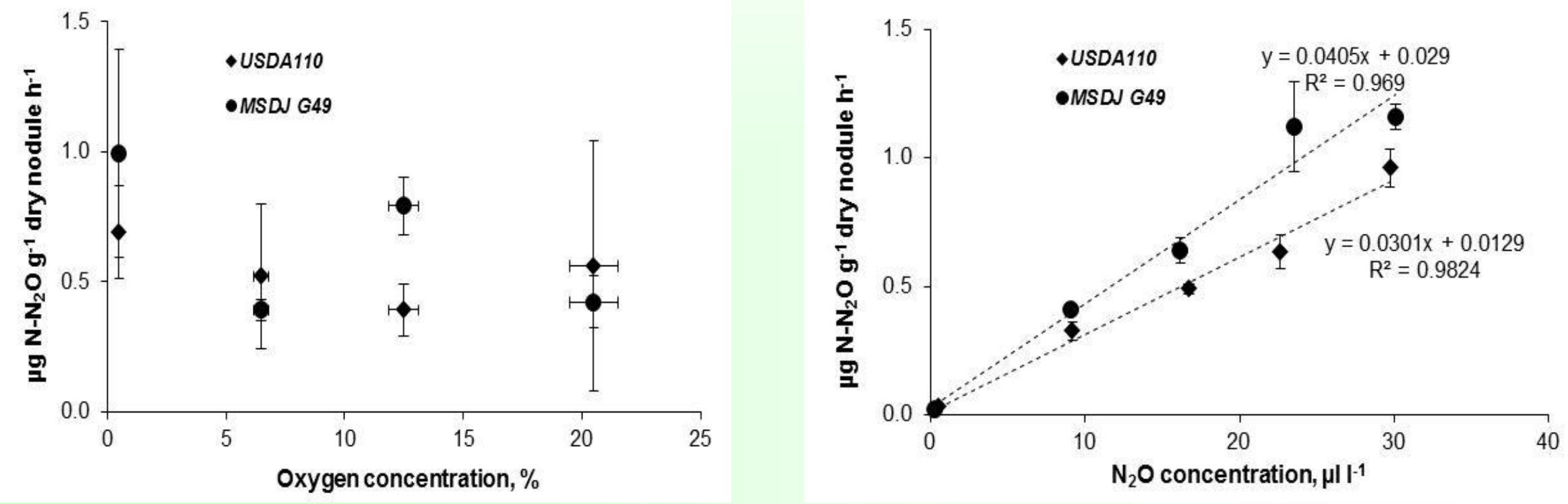


\section{QUANTIFICATION BY A MODELING APPROACH}

THE MODEL

A new version of the NOE model (Hénault et al., 2005) that includes the reduction of $\mathrm{N}_{2} \mathrm{O}$ by rhizobia

Parametrisation of the model using results obtained during both the laboratory and greenhouse experiments

$\mathrm{N}_{2} \mathrm{O}$ emission by soil by nodules inoculated into soybean in a hypothetical system including active nodules
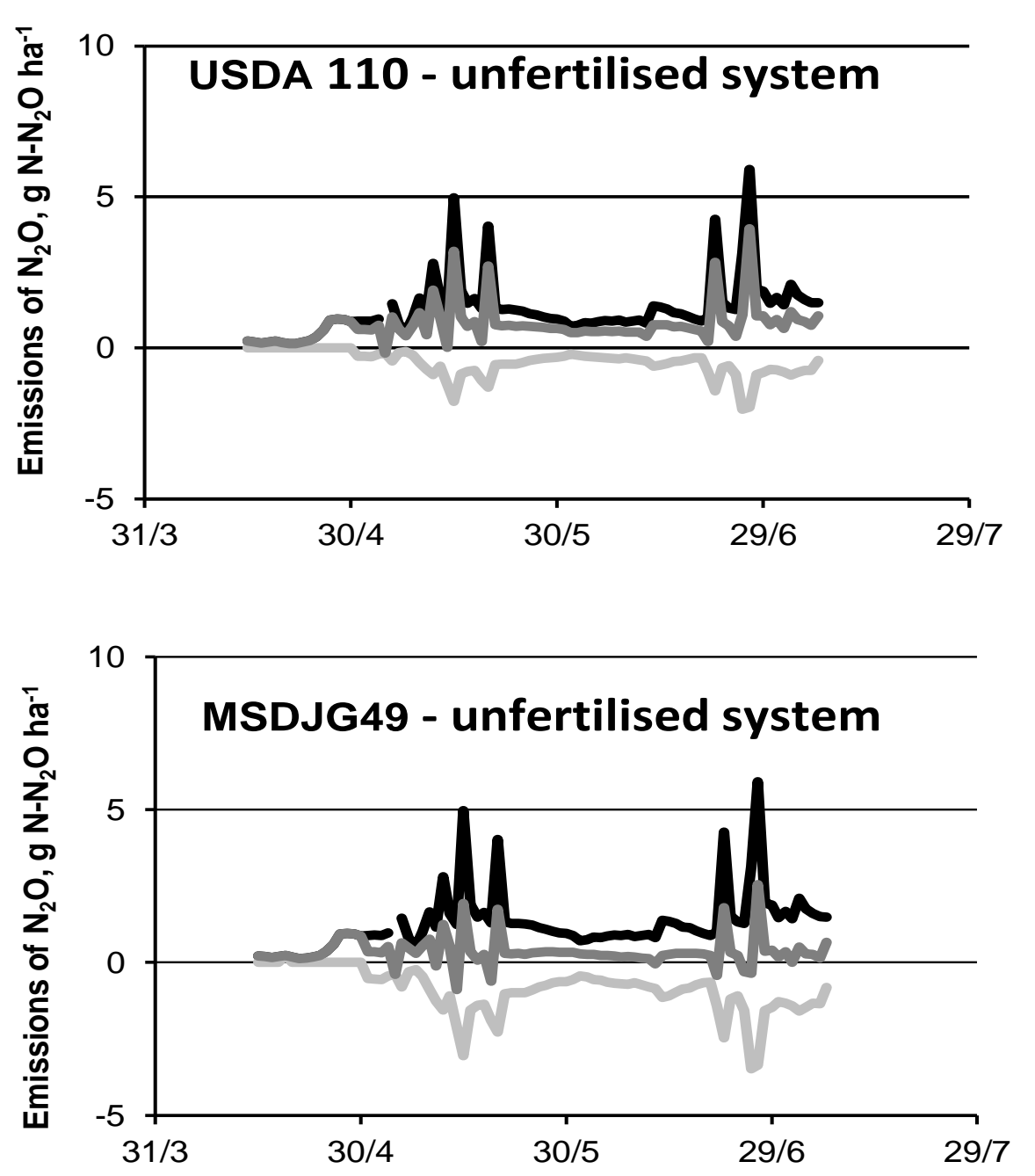


\section{CONCLUSIONS}

- Switch from an $\mathrm{N}_{2} \mathrm{O}$ emitting system to a consuming one by means of the inoculation of strains containg the nos $Z$ gene

- Observations

- that the process is insensitive to the $\mathrm{O}_{2}$ concentration

- that rates increase with the ambient $\mathrm{N}_{2} \mathrm{O}$ concentration

- that the efficiency of the process is strain dependant

- Assessment of a significant benefit of the process at the field scale

$\Rightarrow$ To measure the environmental benefit of the process on the field scale 


\section{Thank you}

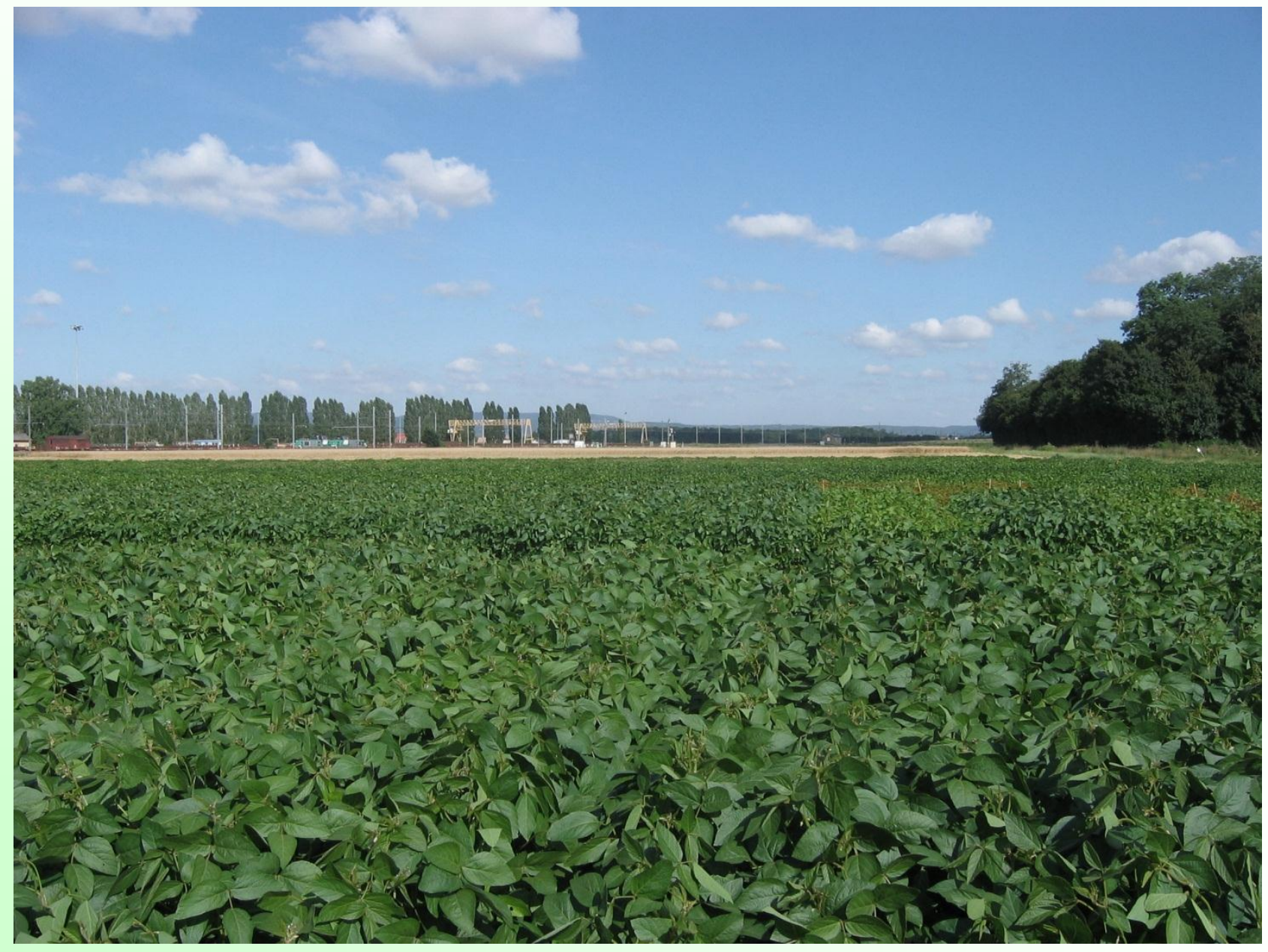

